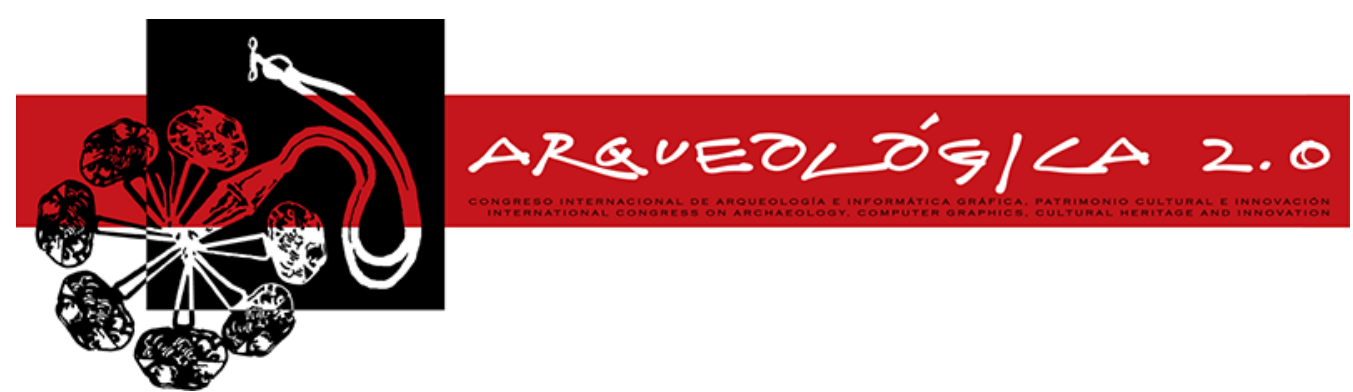

Proceedings of the $8^{\text {th }}$ International Congress

on Archaeology,

Computer Graphics,

Cultural Heritage and Innovation

'ARQUEOLÓGICA 2.0'

in Valencia (Spain),

Sept. $5-7,2016$

DOI: http://dx.doi.org/10.4995/arqueologica8.2016.2982

Received: 02/03/2016

Accepted: 09/04/2016

\title{
DIGITAL RECONSTRUCTIONS - A METHODOLOGY FOR THE STUDY, PRESERVATION AND DISSEMINATION OF ARCHITECTURAL HERITAGE
}

\author{
RECONSTRUCCIONES DIGITALES - UNA METODOLOGÍA PARA EL ESTUDIO, CONSERVACIÓN Y \\ DIVULGACIÓN DEL PATRIMONIO ARQUITECTÓNICO
}

Ana Gil

CERIS, DECivil, Instituto Superior Técnico, University of Lisbon, Avenida Rovisco Pais, 1049-001 Lisbon, Portugal. ana.c.gil@tecnico.ulisboa.pt

\begin{abstract}
:
The architectural heritage is a particular case from the immaterial and material assets, movable or immovable, constituents of the cultural heritage. It is presented as a complex system with a continuous historical process, which can not be dissociated from its surroundings (Brusaporci 2015).

In order to study, preserve and disseminate the past and present reality of this type of heritage, it was developed a digital recostruction methodology, able to adapt to each specific case, both in the object nature and in the representation objectives. This is only possible due to the last decade technological advances, that, alongside with the hardware and software development, led to the digital heritage definition.

In order to disclose and discuss the proposed methodology, is presented digital reconstructions of monuments that have marked and still mark the image of the city of Lisbon. European city, capital of Portugal, country of aqueducts, rich in religious and military architecture. To cover their specific needs, taking into account their different natures, is presented the following case studies: 1) particular case of an extensive monument - the Águas Livres Aqueduct - and the case of territory circumscribed monuments in different preservation states (demolished, remains or existent). This last includes three representative convents of Lisbon's religious houses: the Nossa Senhora da Piedade da Esperança Convent, the Santíssima Trindade Convent and the Santo Antão-o-Velho College.

The developed digital reconstructions were based on the London's Charter and Principles of Seville, in order to ensure the intellectual and technical rigor, as well as the methodological computer-methods visualization work sturdiness. Thus, the developed methodology is scientific, cyclical and flexible based on the creation of digital models with associative and parametric geometry - BIM models (Building Information Model) - intended to include the architectural heritage study, conservation and dissemination.
\end{abstract}

Key words: Heritage architectural, virtual reconstructions, Digital Heritage, London Charter, Seville Principles, BIM

\section{Resumen:}

El patrimonio arquitectónico es un caso particular entre los bienes inmateriales y materiales, muebles e inmuebles constituyentes del patrimonio cultural. Se presenta como un proceso histórico continuo que no puede ser descotextualizado de su entorno (Brusaporci 2015).

Con la intención de estudiar, preservar y divulgar la realidad pasada y presente de este tipo de patrimonio, fue desarrolada una metodología de reconstrucción digital capaz de adaptarse a cada caso concreto, tanto por la naturaleza del objeto estudiado como por el objetivo final de su representación que apenas es posible por los avances tecnológicos de la última década que llevarán al nacimiento del concepto de património digital y, paralelamente la innovación y/o perfeccionamiento del hardware y software próprio.

La manera de exponer y discutir una metodólogia desarrollada que muestra las reconstruccines digitales de los monumentos que marcan la imagen de la ciudad de Lisboa. Por la forma de cubrir sus necesidades específicas y teniendo en cuenta sus distintas naturalezas será mostrado el caso particular de un monumento en concreto, el Acueducto de las Águas Livres, el caso de monumentos circunscritos en el territorio de los distintos estados de conservación con tres conventos representativos del universo de los conventos de Lisboa: El convento de nuestra señora de la Piedad de la Esperanza, el convento de la Santísima Trinidad y el colegio de San Antonio Viejo. 
Las reconstrucciones virtuales elaboradas tuvieron como base la Carta de Atenas y los principios de Sevilla como forma de asegurar el rigor intelectual y técnico así como la solided metodológica del trabajo de visualización informatizada. De este modo, la metodología desarrolada, científica de manera cíclica y flexible basada en la creación de los modelos digitales de geometría asociativa y paramétrica. Modelos BIM (Building Information Model) pretende abarcar las vertientes del estudio, conservación y divulgación del patrimonio arquitectónico.

Palabras clave: Patrimonio Arquitectónico, reconstrucciones virtuales, Patrimonio digital, Carta de Londres, Principios de Sevilla, BIM

\section{Introduction}

The responsibility for the cultural heritage belongs to us all, whether in the community, the city, the region or country and we must ensure that it is preserved as a legacy for future generations. This paper aims to present, discuss and validate the established methodology, for architectural heritage study, preservation and dissemination through digital reconstruction. It is intended to be:

- Scientific, where the created models can be considered scientific models, based on solid sources, originating well documented and accurate results. Thus, fulfilling all Principles of Seville, guiding, in a general way, the flow of information between people, software, files and formats, and where the developed elements are easily integrated into the project chain, enabling its access, through the dissemination platform, to all users.

- Cyclic, where the developed models have the ability to be corrected at any time, without the obligation to rebuild them, enabling the results dissemination and their subsequent correction without losing the technical rigor and without depriving the general public of continued disclosure. Making it possible, at any stage, to interrupt and start, allowing an expeditious disclosure of the available data.

- Flexible, adapting to the final objectives, allowing, first, to skip unnecessary steps and disclose the results at any stage, if necessary, and, secondly, to incorporate more appropriate tools to the objectives and to integrate new software or hardware. It is intended that each case is a case, as it is not the model that depends on the methodology but the methodology that depends on the model, establishing guiding lines.

Initially, the extensive monuments issue appeared, since the size and the wide extent territory occupation hindered the survey and subsequent maintenance, as well as studies and dissemination. In this sense, is presented the Águas Livres Aqueduct, the largest extensive monument of Lisbon metropolitan area, in which only small sections are well known to population (Gil 2011; Rua and Gil 2014).

EPAL (Empresa Portuguesa das Águas Livres), the entity responsible for the management and maintenance, did not have enough accurate information about it, and the one they had was not in digital format. This was an opportunity to generate useful data for its management and maintenance, as well as allowing it to be studied and disclosed in its totality. Thus, the main premises were:

- To study the aqueduct main section and its branches (secondary aqueducts), in order to acquire expeditiously geocoded data, as well as the constituent geometry shapes. Data that could be integrated into the company's geographical and alphanumerical database system, in order to optimize the monument management and maintenance.

- To develop digital model's by-products that enables future studies or analysis, and consequent storage in the company's database.

- To develop digital model's by-products in order to assist its dissemination, through its incorporation into the Water Museum exhibition content.

In a second stage, there was a concern to adapt the methodology used in the aqueduct to all kind of monuments, supporting the work of technicians and non-technicians.

In this context, the LxConventos research project (PTDC/CPC HAT/4703/2012) appears with the aim of studying, in a systematic and integrated way, the impact of the religious orders extinction in the development, function and image of the city of Lisbon (Mégre and Silva 2014). The project's study area is limited to the current Lisbon city area and as case study all existing convents (81 convents) until extinction date (1834). Were selected three convents as representative cases of Lisbon's religious houses: the Nossa Senhora da Piedade da Esperança Convent, the Santíssima Trindade Convent and the Santo Antão-o-Velho College, in different preservation states (demolished, remains or existent), respectively, all with different needs.

Because of the size and complexity of the study universe, the project goals accomplishment was only possible through a coordinated multidisciplinary work. Also, the use of technologies, equipment and programs to inventory, analyse, generate results and represent information, became inevitable due to the data project quantity and diversity. So, to compile all the information and to make it available to general public, it was used two main databases: 1) the Inpatrimonium for alphanumeric data, bibliographic, graphic and image repository; 2) ArcGIS - as Desktop platform (ArcMap) for geocoding, spatial analysis and map generation. This information was disclosed through the project website (http://lxconventos.cm-lisboa.pt/), through ArcGISserver - as an integrating storage and spatial data platform availability, web services and webmapping features creations and InWeb, for Inpatrimonium content broadcast (Fig. 1). 


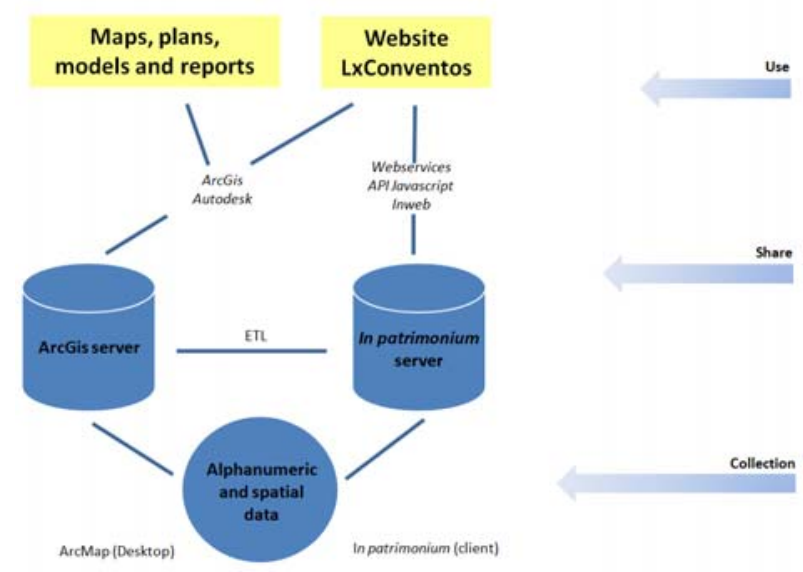

Figure 1: The project information system scheme.

Thus, regarding the selected case studies graphical data production, the main aims were:

- To geotag constituent elements (church, convent, and ground convent) at the extinction and current date, so that it could be studied the impact on an urban scale.

- To study the architectural evolution of the convents at the time of extinction and what has persisted to the present day, with digital reconstruction of three emblematic cases.

- To generate models and data able to integrate the project database, with subsequent availability by an easy and intuitive disclosure in the project's site.

This article is organized in four parts. The first part exposes the acquired importance of today's digital heritage in the cultural heritage field. The second part presents the methodology developed to achieve the stated objectives. In the third, the case studies are presented and analysed. And lastly, the final conclusion is made and future developments are identified.

\section{From the heritage records to computer-methods visualization}

Heritage is understood as part of man's work, in which a community recognizes values and identifies with it. Memory, in turn, is a testimony of past generations heritage and leads to cultural identity consciousness, where the assimilation by the community has a key-role in its preservation and protection through education, research, science and tourism.

The earliest known examples of concern with objects of the past appears in antiquity, but it's with the humanists, in the Renaissance, that is born the awareness of the past's true distance through literary collections, historiographical investigations and graphic surveys of ancient Rome architectural traces.

Following these concerns, a bit all over Europe, throughout the nineteenth century, national heritage protection laws were introduced and entities responsible for the protection and preservation of architectural and / or archaeological heritage were created. In 1931, Athens Charter is written as first normative act exclusively dedicated to heritage. This sets out the need of each country to publish an inventory of the existent heritage, as well as archives creation, with all documents related to historical monuments.

Since then, there have been outlined new concepts and concerns in cultural heritage field, through charters, recommendations and international conventions by UNESCO, COE and ICOMOS. It stands out: the historical monument definition and the importance given to its surroundings (Athens' Charter in 1931); definitions of architectural heritage (European Charter of Architetural Heritage in 1975), historical gardens (Florence Charter on the protection of Historic Gardens in 1981), historical towns and the inhabitants recognition of their importance in the participation and involvement for successful heritage protection (Washington's Charter in 1987); Archeological heritage definition (International Charter on the Archaeological Heritage Protection and Management 1990 corrected by ICOMOS in the International Charter on Underwater Cultural Heritage Protection and Management in 1996); And the cultural tourism recognition as a benefit to the cultural heritage (International Charter on Cultural Tourism in 1999).

With the digital Era, the paradigm changed. ICT (Information and Communication Technologies), combined with the new means of communication, the World Wide Web, have originated a new kind of heritage - digital heritage - recognized by UNESCO in 2003, by the Charter on the Preservation of Digital Heritage. It was clear the importance of heritage information production and distribution through digital means, with easy access, to ensure its transmission to future generations. However it is recognized the weak support, from software and hardware, and it is given to each nation the responsibility for data production and archive, including libraries, archives, museums and public heritage institutions, fomenting education, research and experiences exchange.

With the technological evolution occurred in the last thirty years, the humanities (history, archaeology and architecture) were able to enhance the heritage study and dissemination through the introduction of three-dimensional digital models as main form of visualization. It has appeared substantial three-dimensional modeling software, file formats, working methods and developed models increased potential (Frisher 2008).

In 2009, the London Charter "defines principles for the use of computer-based visualization methods in relation to intellectual integrity, reliability, documentation, sustainability and access. (...) The Charter therefore does not seek to prescribe specific aims or methods, but rather establishes those broad principles for the use, in the research and communication of cultural heritage, of computer-based visualization upon which the intellectual integrity of such method and outcomes depend" (UNESCO 2009).

In 2012, The Principles of Seville intend to increase the applicability of the London's Charter on a cultural heritage specific field: archaeological heritage. Eight fundamental principles are presented: Interdisciplinarity, purpose, complementarity, authenticity, historical rigor, efficiency, scientific transparency, education and evaluation (SEAV 2012). 
The Principles of Seville came to define three categories in which the created scientific three-dimensional models must be built for: dissemination, study and maintenance. In turn, regarding the historical rigor, it highlights the importance of a strong research and documentation, stating photogrammetry and laser scanning as techniques that increase the quality of scientific data. Also, expressing scale evidence (Aparicio and Figueiredo 2010) to distinguish the different accuracy levels of the developed model.

This evolution allowed Humanities to adopt AEC industry (Architecture, Engineering and Construction) BIM methodology (Eastman et al. 2011), in the preparation of architectural heritage scientific three-dimensional models. Thus, the developed models altered from simple nurbs to three-dimensional parametric models with associated databases.

The HBIM (Historical Building Information Modeling) is a BIM feature associated to historic buildings and an attempt to automate architectural canons reproduction (Murphy et al. 2011).

In a general way, BIM came to offer new forms of knowledge management for architectural heritage regarding its documentation, preservation, maintenance (Fai et al. 2013) and disclosure, enhanced by the libraries creation of historical architectural elements and surveys integration by photogrammetry and laser scanning (Santagati 2005) (Garagnani and Manferdini 2013). This type of survey has undergone significant advances, in terms of hardware and software, making expeditious and low-cost surveys, hence multiplying its use among experts in the field.

In Portugal, the first steps in BIM have begun with groups like BIMForum Portugal, BIMClub (BIMForum Portugal 2014) and technnical commission CT197. Regarding computer-methods visualization applied to architectural heritage, there are not known examples that allow to simultaneously potentiate its preservation, dissemination and study. As the closest examples, there are projects such as: City and Entertainment: $A$ view of Pre-earthquake Lisbon, which aims to virtually recreate the memory of the destroyed city caused by November 1th, 1755 earthquake, using Second Life virtual world technology for disclosure (Murteira and Rodrigues 2014); Olisipo Reconstitution and a corbita type Roman ship a past reproduction and interpretation, based on archeology scientific illustration methods, that seeks to represent how ancient Lisbon would have been, disclosed by a documentary "Roman anchorage in Olisipo". These models are only applied to the disclosure category. However, since they are not constituted by parametric and associative elements based on an associated database, it hinders the process of incorporating new data of more complex studies, or its adaptation to maintenance situations where structure still exist.

In this context, it is highlighted $L x$ Conventos project role, which through a multidisciplinary team dedicated to the architectural heritage specific characteristics, generates Lisbon's Convents useful data, used in its study, dissemination and preservation, all stored and available to the community in digital format.

\section{Digital reconstructions - a methodology}

Nowadays, the development of scientific $3 \mathrm{~d}$ models has increased rapidly, as well as the methodologies and tools used by the purpose for which they are intended to, as stated by the previous section.

The developed methodology (Fig. 2) is scientific, cyclical and flexible as explained before, based on as-built digital models creation with associative geometry and parametric - BIM models - intended to be used, simultaneously, for study, preservation and dissemination of architectural heritage.

According to this, the data goes through three main stages: 1) Acquisition, made by research and survey, 2) Interpretation and treatment, and finally, 3) Communication, made by modeling and visualization. It is possible to make studies and analysis in any stage, more common in stage 2 and 3.

Follows a brief description of each of these phases.

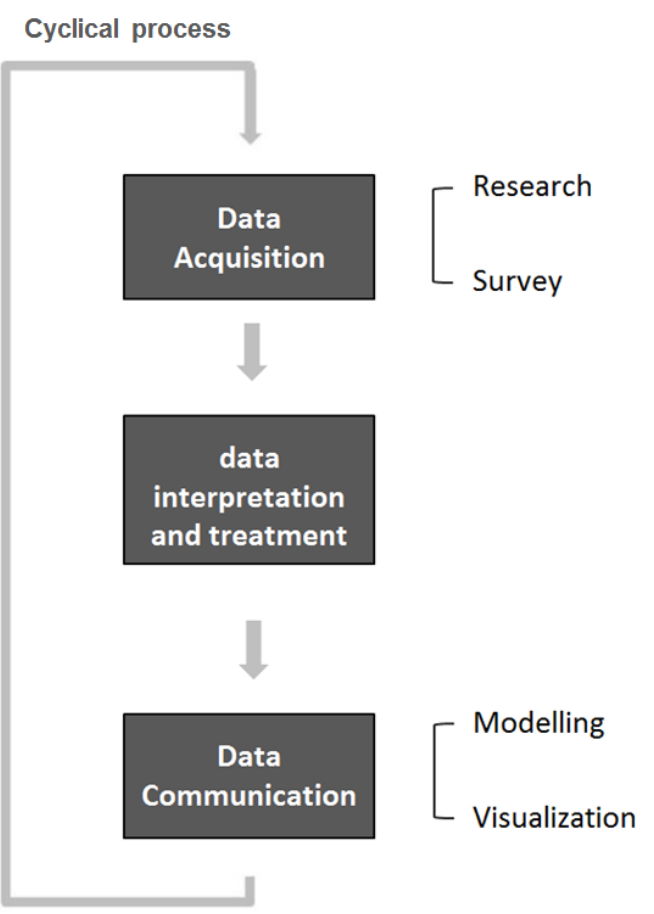

Figure 2: Developed methodology for the development of architectural heritage virtual reconstruction.

\subsection{Research}

At this stage it is highlighted interdisciplinarity, where historians, archaeologists, architects, among others, research, dialogue and share information. Consists in, gathering research and information in digital archive files and libraries, regarding the monument in study: written documents, old photographs, iconography, cartography and levels.

It is necessary to make a first geographical approach to the monument, be it in extension or territory limited, punctual approach done by photo-interpretation and using geocoding program. 


\subsection{Survey}

Based on the research stage gathered data, field work is done to verify the studied architectural element current state. Depending on the initial data quantity and quality, in the presence of visible architectural structures, it is carried out the intended survey or just field data confirmation. The methodology at the survey stage, allows for direct and indirect methods (Manual measurement with the aid of measure tape and distancemeters) and indirect (laser scanning and / or photogrammetric).

The choice of method will depend from case to case. On one hand, by the type of monument and its conservation state and, on the other hand, by the final model required level of detail, always having in mind that the surveyd data will be modeled in a BIM modeling tool.

To monuments where it is required milimeter surveying, it is advised to use laser scanning. It is now possible to go to milimiter accuracy, even in adverse wheather conditions (with Leica Geosystems P40), in case of specific monuments, and in case of monuments in extension, it is possible to use laser scanner mobile devices producing little or no cloud noise. In the case of roof surveys, it is advised the use of a drone with a photographic machine, to complement the laser scanning cloud.

This being an extreme and ideal case, it is not sustainable to do an exhaustive indirect survey of all building elements. In this case the most common solution is, based on existing drawings or in a first draft made after photo interpretation, the survey to be initiated by direct methods using manual measurement (with the help of tape measure and distancemeters) for main dimensions (length, width, height and position of elements, such as doors and windows) complemented by a photographic survey and, in some specific cases, by laser scanning and/or photogrammetric survey.

The laser scanning is made for large areas where you need to collect countless types of detail, such as cloisters, that consist in several elements like columns, arches, vaults, gaps and floor levels. It is possible to systematically make a complete survey of all necessary data without a huge effort, pre or post survey.

The photogrammetric survey, currently being used to cover large areas to only small details (depending on the desired accuracy), for these situations it is only used in individual elements in which is necessary to have rigorous survey, such as columns and statues. It is a more economical and expeditious process.

Regarding indirect surveys, we must highlight the operator role. Although it being an expeditious process with easy data treatment where exists a reverse modeling process, where the data analysis and treatment is mostly made after its acquisition, the subsequent modeling is dependent on the survey quality. An experienced operator does all the difference in terms of results and time spent before, during and after the survey.

Regarding the choice of equipment, it points out:

- Manual survey - laser distancemeters are preferred in expedited measurements at the expense of sound distancemeters, especially if it is outdoor measurements or are non-homogeneous surfaces.

- Laser scanner Survey - The main factors for laser scanner equipment choice are: the intended rigor alongside the type of surveyed monument (as stated before), software support to process all the collected data with easy integration in the work process and technical support.

- Photogrammetry - a wide-agle lens camera it is a good choice, since it will be used only for singular objects survey of the studied monument. The operator is essential in the whole process and has to consider: orientation, restitution, design and photo execution, number and shots position.

\subsection{Interpretation and data treatment}

Intermediate stage that allows to develop macro and micro scale relevant work, which contributes to the comprehension and consequent final architectural representation - Digital reconstruction.

At the macro scale, there is a city scale geocoding and cartographic development analysis, in GIS software (Geographic information System) supported by CAD (Computer aided Design) and sometimes by alphanumerical database, that allow us to have the correct studied architectural set location and its evolution over time.

In turn, at micro scale, we have a building's scale analysis. On one hand, with architectural rules systematization and architectural evolution, in CAD software, and on the other hand, the intermediate elements development based on laser scanner or photogrammetry cloud point, each with its particular software.

The used software and the reasons for their selection were:

- GIS - for expedite works that are not part of an extensive work chain, it is possible at an early stage to use Google Earth. However, already exists specific freeware with good functionality and practical use, as is the case of Qgis, open source software. In these cases it is advisable for its accuracy and available features. In general, in the present methodology, for most cases, it is used ArcMap, because it is interoperable with CAD software and BIM, CIM (City Information Model) modeling software since it has good data sharing capabilities both locally or through web services for global dissemination via internet, thus enhancing both the modeling and dissemination stage.

- CAD - highly effective support software, usually Autocad, despite other existent freeware softwares that in some cases can satisfy the needs. In general, AutoCad, of all, it is the one that has more functionality and potential, because there is always the possibility to automate procedures using its own programming language (VLISP). 
- Laser scanning - since it was chosen Leica Geosystems hardware, it is preferred the use of LeicaCyclone, software that lets you make the correct cloud point treatment and its preparation for the ultimate modeling software import. It is also available the CloudWorx Revit plug-in that allows direct cloud modeling. However it is not excluded the existence of other softwares that enables cloud treatment, surface generation and even BIM software plug-ins. These two are the selected ones taking into account all of the methodology proposed premises.

- Photogrammetry (structured for motion) - Photoscan was choosen by allowing photo integration from different equipment's, demonstrating to be expeditious and rigorous software.

Regarding the stage analysis, it is given emphasis to recent developments that allows the inclusion of a quantitative method of urban analysis - Space Syntaxe (Hillier and Hanson, 1984) - within GIS software. This possibility has been increasing the number of analysis variables and consequent study types, since it may resort to both cartographic data as to GIS software database existing parameters (Gil et al. 2015).

Thus, at city scale, it is possible, in QGIS, to analyse the surroundings in an integrated way with the plug-in 'Space Syntax Toolkit' (SST) which integrates depthmapX software in QGIS environment. This GIS software is not preferred, but it easily imports and exports in an effective way the ArcMap developed data.

\subsection{Modeling}

The survey stage and data processing allows the knowledge acquisition of the studied building, concerning its elements features and nearby surroundings. After that, modeling can start. It is the first communication stage.

At this stage, the elements are modeled according to the desired LoD (level of detail), however you can use the same model for future works that need a different LoD.

To accomplish this, it's used BIM software, the methodology main component, which allows the methodology to be cyclic. Because it allows to apply characteristics elements with an identity in the project, rather than only solids or surfaces, devoided of information. These softwares also have associated databases that allow to manage the entire project and its elements in an effective way.

It is possible, at this stage, to use colour scale to determine the epoch constructive elements, by using the phase software. Regarding the colour different veracity levels used by archaeologists, it is also possible, but it is not usually used in architecture.

In the carried out modeling, it was decided not to use a colour scale to represent the different veracity levels, as suggested by The Principles of Seville, since the elements are only modeled upon the existence of sources that justify it. Thus, the LoD of each modeled element depends on the detail of the origin source level.

The chosen modeling software was Revit, since this:
- Allows laser scanning integration in a quickly and expeditiously way, in particular, point clouds that originated from Leica Geosystems laser scanner, through Leica CloudWorx for Revit, as well as different types of files, such as CAD and GIS software, like Autocad and ArcMap, thus ensuring the developed models intellectual and technical rigor and scientific features.

- Possesses parametric and associative properties that allow elements parameterization - families (Fig. 3) - and development of associated database. The elements can be corrected at any time, and be in constant disclosure, without interfering with the research work.

- Allows to generate technical data and information to the general public, easily adding the models in the project chain, which will be described in next stage.

Regarding modeling sets / sites, for the surrounding case study, preference is given to City Engine, CIM software (city Information Model).

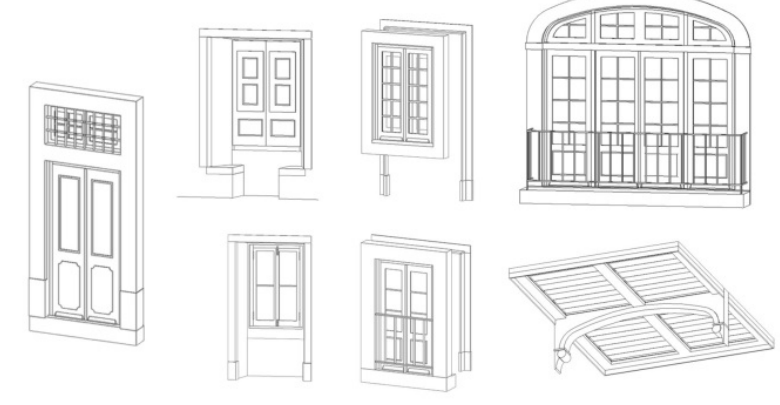

Figure 3: Santo Antão-o-Velho College: exemple of the main developed families.

\subsection{Visualization}

The final results may be, as first observed in The Principles of Seville, to study, preserve and disseminate. The present methodology does not intend to exclude any possibility, in other words, you can generate visualization forms mainly aimed for technicians, for studies and preservation, or to the general public, as a way of disclosure.

As visualization methods for technicians, are available: Revit models (with all stages and associated tables), point clouds and GIS file format (ArcMap). In turn, to the general public, it is possible to produce different file types in different formats, such as renders and videos (produced in LeicaCyclone or Revit), which are the easiest to understand, and technical drawings (sections and levels) and 3D pdf, a little more complex, but more complete in its content. In neither case, the average user needs to install any specific viewing software.

At this stage, in addition to elements that can be directly developed from previous stages software, highlight is given to serious games, game engines or educational game development, with a variety of goals with easy and expeditious use. Blender and Unity are suggested. Blender is freeware and has an active community, both in support as in new applications, and features development. Unity, in turn, integrates more satisfactorily 
in the present methodology, since it has a greater interoperability between modeling software due to already existent well-defined paths, regarding web deployment and mobile applications.

\section{Case Studies}

"At micro-scale level it is possible to find subtle metamorphosed architectural remains in ancient convents places given as demolished" (Sequeira 1939).

Without heritage presence awareness it is not possible to exist a common will to preserve. A watchful eye can always awaken the collective memory. It is the technician's role to take the first step towards enhancing this memory through reliable disclosures.

Therefore, the present case studies were chosen due to their partial or total ignorance by part of the general population, by its specificities as an extensive monument and by punctual monuments. They have different types and existent documentary information quantity, different preservation states and consequently, different needs. Therefore, it is intended to disseminate the architectural heritage, and at the same time, to be used as case study to the methodology improvement, so it can be applied in a broader range of monuments.

The Águas Livres Aqueduct construction, Portuguese National monument, started on May 16th 1731, and concluded at the year of 1748. The aqueduct, its branches and its distribution gallerys, have a $58 \mathrm{~km}$ extension total. The main section has $14.20 \mathrm{~km}$ of length, and includes about $8 \mathrm{~km}$ of trenches, $4.2 \mathrm{~km}$ of tunnels, and $2 \mathrm{~km}$ of arches, where $0.941 \mathrm{~km}$ are in Alcântara valley. This section was bridged by building 35 arches, 14 of them ogee and the largest is $65 \mathrm{~m}$ tall and $29 \mathrm{~m}$ wide. The distribution structure remained operational until the mid-twentieth century, but it has been merely ancillary since 1880 .

The Lisbon Convents are city's symbolic landmarks. It is composed by grounds and church, each possessing specific types accordingly to its religious order.

The 1834 religious order extinction was decisive to nineteenth century Lisbon's urban development, where around 130 religious houses were disaffected, received profane occupations, demolished or changed.

At present time, a new cycle begins, with government sale, of nationalized heritage. Efforts have been made to give accurate studies that allow well thought decisions that safekeep the existing heritage values, linking them with new social, cultural and tourism needs.

For this work it were choosed three Lisbon's Convents:

- Nossa Senhora da Piedade da Esperança Convent, Santa Clara religious feminine order convent, was constructed in 1527, only remains exist at the present date.

- Santíssima Trindade de Lisboa Convent, Trindade, Santíssima Trindade para a Redenção dos Cativos religious feminine order convent, was funded in 1218 , and is partially demolished at the present day.

- Santo Antão-o-Velho College, Coleginho, companhia de Jesus masculine order college, was constructed in 1542 and still exists at the present day.
Next, will be presented the obtained main data for each case study, taking into account the methodology stages and respective digital reconstructions results. Results that are intended to serve both the technical and the general public in an effort to keep the identity and collective memory.

\subsection{Aguas Livres Aqueduct}

The Águas Livres Aqueduct, regarding existing documentation, it had topographic data (military charts at 1: 25,000 and Lisbon chart at 1: 1000) and the main section plan and longitudinal profiles from all aqueduct and subsidiaries, with bailing slope values, angle and length between vertices, gutter fund quota, distance from the origin and mileage.

Based on this documentation, it was necessary to carry out geocoding and local survey of some unidentified points, as well as, an element of each turret type to proceed to its parameterization, taking into account their main features.

The whole process is described in the Table 1, such as stages, data types, needed software types and used software.

Given that it was intended a low-cost process, freeware software was used whenever possible. However, the used methodology was optimized in three stages by replacing some software.

In the acquisition and data processing, by the replacement of Google Earth by ArcMap, and Excel database for Access, allowing to remove the Autocad use and Scheme programming. The geocoding would be made directly into ArcMap, associated with an Access table. ArcMap file could then be easily linked to Revit to be used as modeling basis.

In data communication, replacing the Blender by Unity, removes the 3DMax conversion formats. It would facilitate the cyclical process in future changes.

This case study was used to prove the expeditiously methodology application on extensive monuments, where there aren't many representative examples.

\subsection{Convents}

Each three convents existent documents and current state, varied from case to case. This caused the survey process to be different in each case, as well as part of the data processing. As a disclosure method, in a general way, there is a Revit model and its $3 \mathrm{D}$ pdf, technical drawings and renders.

It is possible, in the Table 2, to observe the synthesize stages, data types, software required types and used software.

Therefore, the methodology has presented itself to be flexible and cyclic, allowing to adapt to existing data in every situation and allowing to incorporate new data at any time.

It will be briefly described each of the three convents, in different situations, so that it is possible to understand what kind of data was attainable to collect before and which elements were created after, based on the same methodology. 


\subsubsection{Santo Antão-o-Velho College}

Santo Antão-o-Velho College, Coleginho, did not have sufficient documentation to ensure an accurate digital reconstruction. However, since it remained nearly intact until the present day, it was possible to obtain an accurate model based on the entire building direct survey, and indirectly, by laser scanning of the cloister, an area of more detail.

Thus, it was possible to parameterize its characteristic elements (Revit families) with high LoD, including: ceilings, windows, doors (indoor and outdoor), columns and arches.

To disclosure, beyond model Revit (Fig. 4), 3D pdf, technical drawings and renders (Fig. 5), it was possible to produce videos based on the point cloud.

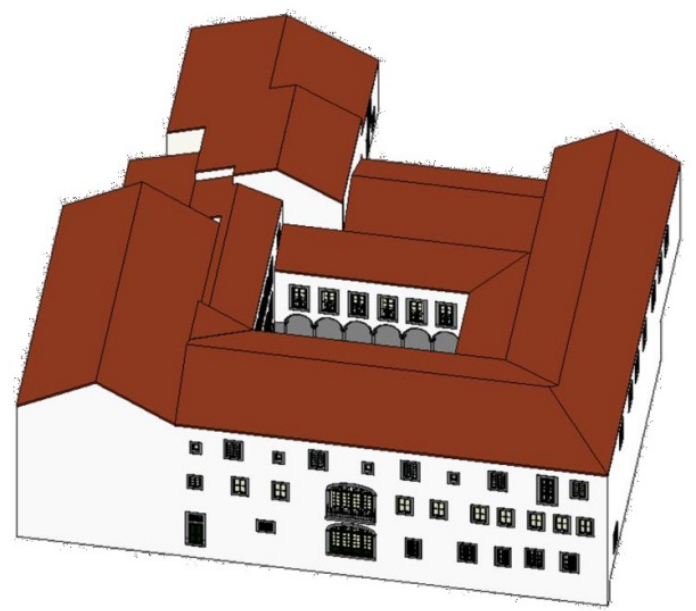

Figure 4: Coleginho - Revit model.

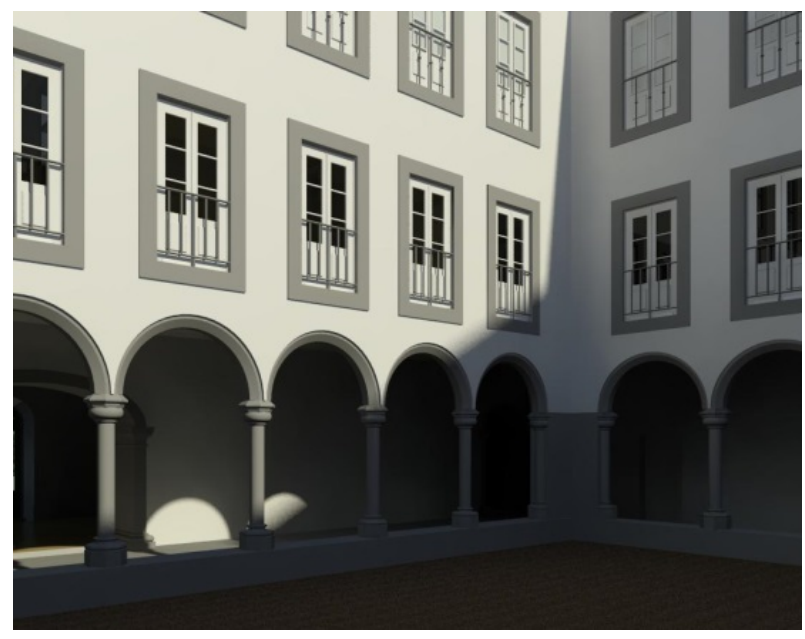

Figure 5: Coleginho cloister - Revit render.

\subsubsection{Nossa Senhora da Piedade da Esperança Convent}

The Esperança Convent, unlike Coleginho, was demolished almost in its entirety, and only remained archway traces of one of the cloister wings that was reattached to the new buildings.

An epoch document together with the extinction process existing plants, were vital in the convent's digital recreation (Fig. 6), since they had descriptions of the convent spaces as well as strict dimensions.

Thus, the archway rigorous survey along with the existing plants allowed not only a rigorous cloister reconstruction (Fig. 7) but also to assign the correct height floor, and therefore rebuild all convent, with planimetric and altimetry accuracy.

However, it should be noted that there are still some uncertainties and low visible LoD in the model, including in the developed families due to missing plans and sections.

Alongside the model digital reconstruction, it was possible to incorporate the space syntax analysis to the convent grounds urban area, and nearby surroundings, in an attempt to comprehend the central urban system relation, which progressed with the city's transformation after the religious order extinction.

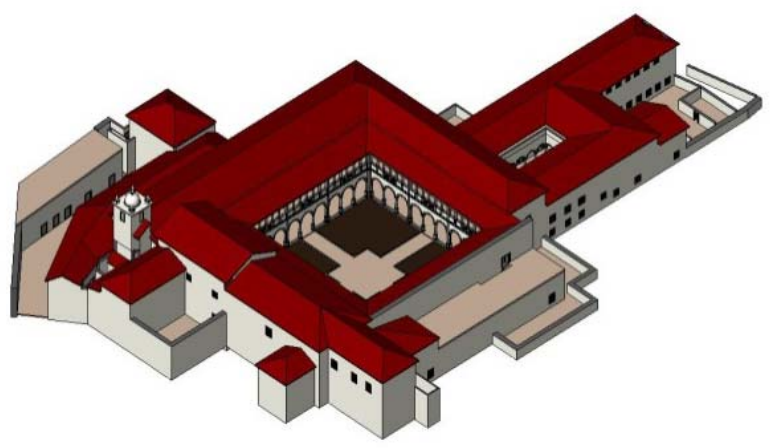

Figure 6: Esperança - Revit model.

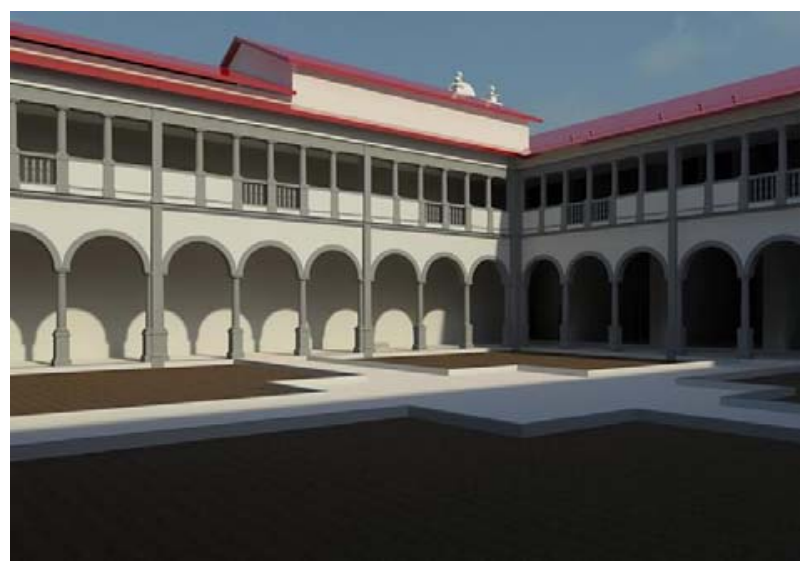

Figure 7: Esperança cloister - Revit render.

\subsubsection{Santíssima Trindade de Lisboa Convent}

The Santíssima Trindade de Lisboa Convent, Trindade, presented itself as the most richest and complex example, due to both high physically and documentary information.

In this way it was possible to do its pre-earthquake representation (although with low LoD), extinction and current date representations, which has a significantly different implementation of both the convent building as to the 1834 existing church (Fig. 8). 


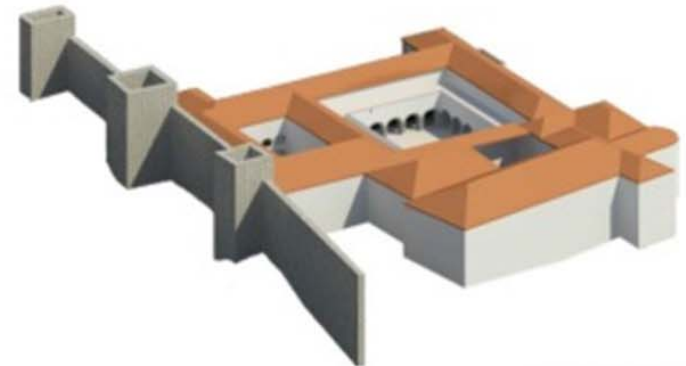

(a)

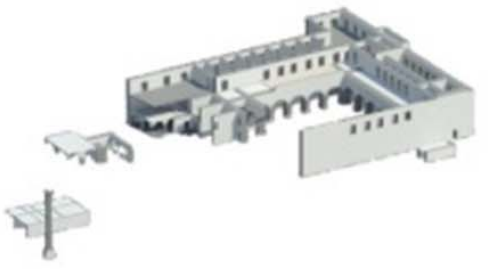

(c)

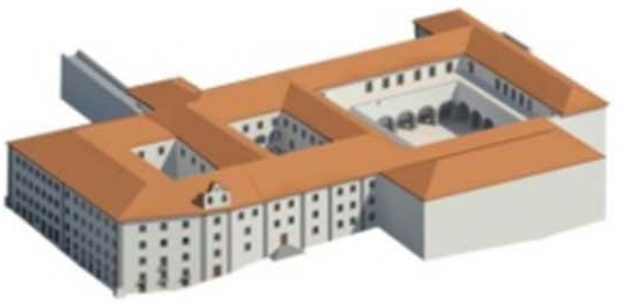

(b)

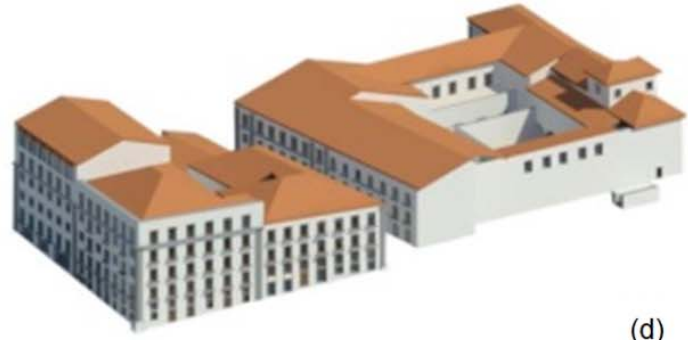

(d)

Figure 8: Santíssima Trindade de Lisboa convent - architectural evolution: a) Pre-earthquake; b) Extinction (1834); c) Conventual architectural remains (2015); d) 2015

Since it was found plenty preexistence, it was necessary to understand the whole planimetry and altimetry, to be able to make associations from present to the past. The site was visited several times and it was conducted a thorough investigation of all documents of the two blocks that corresponded to the convent implementation to extinction date. Reciprocal information existed. On one hand, based on the first floor plan, included in the extinction process, it was possible to discover preexistence in the current buildings. On the other hand, based on visits to the site and documentation, it was possible to draw conclusions of how would the stores area should be like (west part of the monastery on the two floors beneath first pavement), since there was no drawings of these, only descriptions that corroborated the drawings and found geometries. It was interesting to note that the past helped present and the present helped the past in the digital reconstruction of this convent.

Regarding uncertainties and low LoD, the situation was similar to Esperança convent. The same question exists in the middle floor definition between the first and the second floor, adding the existing doubts of the second floor level since the existing plant is only partial. As well as the families low LoD due to lack of sections and plans. In this case, the iconography of the convent and church main façade was determinant to define the modeled elements.

\section{Conclusion and future developments}

"By the moment the London Charter is the most important document approved by the international community in the field of cultural heritage and new technologies, and is, therefore, a consultation document required for all researchers who in one way or another working in this field." (SEAV 2012)

In heritage preservation and disclose work is essential to follow guidelines that allow to create rigorous models through consistent procedures. Thus, the London's
Charter guidelines, as well as The Principles of Seville, are fundamental.

Regarding general principles, multidisciplinary, is an essential topic to obtain and disseminate more and better results. In this case, the $L x$ Conventos project is an example, whose final results are due to the architects, historians, geographers, restoration and computer technics, joint work.

However, can be suggested some adaptations to the principles taking into account the architectural heritage specificities in relation to archaeological heritage. An example is the relevance of colour scale use to represent different construction periods (when there are more than two identified periods), rather than the scale used by archaeologists (Historical/Archaeology Evidence Scale) to represent the different veracity levels, which is not so important in these cases.

Regarding architectural heritage digital reconstruction, in general, it is possible to point out some important future developments:

- Architectural heritage recreations and digital reconstructions general principles conception, different from The Principles of Seville, taking into account its specificities;

- Ontologies definition;

- Technical and theoretical multidisciplinary work. That will allow interests and efforts convergence, enabling more analysis and parallel studies, alongside each individual work, based on the same data;

- Disseminate methods, management and data storage processes, in order to correctly preserve it.

- GIS and its databases development in order to incorporate architectural heritage digital models without subsequently data loss;

- BIM models use in a general way; 
- BIM modeling standardization and automation, through families creation directly from the cloud point, already happenning in the AEC industry or HBIM approaches.

It is possible to conclude that the three fundamental elements to a good end result are the people, the method and the software / hardware. The technician has a major role in the method and software/hardware choice, in an interoperable way, more suitable for the entirety work development.

Regarding the used methodology, as originally proposed, it aimed to follow guidelines, and proved to be scientific, flexible and cyclical. It stands out:

- Model development and its disclosure, without all available data. In the case of the aqueduct, there was only an initial fast survey that allowed its early disclosure, followed by its on-going improvement. In the case of the convents, especially in the Trindade Convent, there was a constant data acquisition for both in site new physical discoveries or new documentation, which did not interrupt the constant model enhancement and disclosure.

- New incorporation techniques in the methodological process without losing its cyclical nature and general public commitment, i.e. disclose easily editable models. It was incorporated: laser scanning, photogrammetry and space syntax analyse. The laser scanning survey integration came to fill the lack of documentation, in the case of still existing structures, such as the Coleginho, allowing a quick, expeditious and rigorous survey of its main characteristic, giving detail and rigor to developed model, and potentiating new disclosure ways. The photogrammetry integration for some specific surveys, allowed to generate non editable models of some particular details. In turn, the space syntax analyse incorporation at urban area level, allowed to understand the local city dynamics.

In order to improve the methodology, the following developments are underway:

- The photogrammetry survey integration in specific non-parameterized architectural details.

- Colours and textures incorporation to create more realistic models, ensuring data integrity in conversion process (rvt, ifc, pdf).

- Colour scale integration to identify different construction periods, simplifying, in an easier and more intuitive way, access to technical data.
- Methodology expansion to virtual recreations by incorporating experiences, i.e. user interactions in virtual space, in order to disclose, in an intuitive way, the different space uses and appropriations, through mobile augmented reality.

- Application of digital models in management and maintenance of existent architectural heritage.

Regarding the four mentioned case studies digital reconstructions, presents itself as technically rigorous, taking into account the existing data and applied methodology (Table 1 and 2). However, it is possible to state the following future developments:

- Águas Livres Aqueduct - developing digital reconstruction and subsequent digital recreation of the aqueduct in its entirety: general section, branches and its Lisbon distribution, including galleries and fountains.

- Coleginho - more broad modeling of its surroundings, aiming to the grounds evolution perception.

- Esperança - historical documentation research continuation in order to be able to correct the model and address the existing representation errors in some specific locations.

- Trindade - a broader modeling of its surroundings, as suggested in Coleginho, and historical documentation research continuation, as suggested in Esperança. It highlights the importance of archaeological data incorporation. This could be relevant in the old church area, contributing to significant pre-earthquake representation developments.

In conclusion, the developed models expose an integrated form of heritage representation and disclosure to technical and non-technical, thus, introducing new dynamic processes. In this particular case, it was disclosed Lisbon's forgotten, or given as demolished, heritage.

Therefore, the present work aims to generalize the presented multidisciplinary and cyclical methodology, through systematic application in architectural heritage study, disclosure and management. It aims to a global notion of cultural identity, which inevitably generates collective memory and consequent desire to preserve.

\section{Acknowledgements}

This work was supported by EPAL (Empresa Portuguesa das Águas Livres); and FCT (Fundação para a Ciência e Tecnoogia) under Grant (PTDC/CPC HAT/4703/2012) to the LxConventos project. 
Table 1: Aguas Livres acqueduct - types of programs / equipments recommended to use in each stage of the digital reconstructions methodology.

\begin{tabular}{|c|c|c|c|}
\hline & & Type of software/equipment & software/equipment used \\
\hline \multirow[t]{2}{*}{ Data acquisition } & $\begin{array}{l}\text { Data collection } \\
\text { (Sources: cartography, project, } \\
\text { photograph e photo-interpretation) }\end{array}$ & Geocoding software & Google Earth \\
\hline & Architectural survey & GPS & portable GPS \\
\hline \multirow{3}{*}{ Data treatment } & Data base development & $\begin{array}{l}\text { database program with programming } \\
\text { language associated }\end{array}$ & Excel + Scheme \\
\hline & Director axle model generation & $\begin{array}{l}\text { CAD program with programming } \\
\text { language associated }\end{array}$ & AutoCad + Scheme \\
\hline & Data to generate the environment & $\begin{array}{l}\text { Gis and CAD programs with } \\
\text { programming language associated }\end{array}$ & ArcGis e Autocad + Scheme \\
\hline \multirow{3}{*}{ Data Communication } & Digital modeling & $\begin{array}{l}\text { BIM program with associative and } \\
\text { parametric geometry }\end{array}$ & Revit \\
\hline & Format conversion & $\begin{array}{l}\text { Program compatible with modeling } \\
\text { softwares }\end{array}$ & 3DMax \\
\hline & Virtual modeling & $\begin{array}{l}\text { Visualization and three-dimensional } \\
\text { interaction program }\end{array}$ & Blender \\
\hline
\end{tabular}

Table 2: Convents - types of programs / equipments recommended to use in each stage of the digital reconstructions methodology.

\begin{tabular}{|c|c|c|c|}
\hline & & Type of software/equipment & software/equipment used \\
\hline \multirow{2}{*}{ Data acquisition } & Data collection & Geocoding software & ArcGis \\
\hline & Architectural survey & $\begin{array}{l}\text { Manual survey equipment and laser } \\
\text { scanning }\end{array}$ & $\begin{array}{l}\text { Tape measure, distanciometer, } \\
\text { laser scanner Leica P20 }\end{array}$ \\
\hline \multirow{2}{*}{ Data treatment } & $\begin{array}{l}\text { database and primary drawings } \\
\text { development }\end{array}$ & Data base, GIS and Cad softwares & Acess, ArcGis e Autocad \\
\hline & Point cloud treatment & $\begin{array}{l}\text { Cloud points and photography } \\
\text { processing programs }\end{array}$ & Leica Ciclone e Photoscan \\
\hline \multirow[b]{2}{*}{ Data Communication } & Modelling & $\begin{array}{l}\text { BIM software able to easily incorporate } \\
\text { cloud points }\end{array}$ & Revit e Cloud Worx \\
\hline & Visualization & $\begin{array}{l}\text { current softwares of data visualization } \\
\text { (video, technical drawings and } 3 D \\
\text { models viewers) }\end{array}$ & $\begin{array}{l}\text { Adobe Reader and media } \\
\text { player }\end{array}$ \\
\hline
\end{tabular}

\section{References}

APARÍCIO, P. and FIGEIRIEDO, C., 2010. Escala de evindencias. Available: http://www.mediafire.com/view/vcl26cuwc66b5m3/Escala Evidencias.pdf [2/29, 2016].

BIMFORUM PORTUGAL, 2014. Building Information Modeling: A new constrution paradigma. 1st BIM International Conference. Porto: BIMForum Portugal. Available: http://www.bimmi.net/index.php/pt/other-editions [2/29,2016].

BRUSAPORCI, S., 2015. Handbook of Research on Emerging Digital Tools for Architectural Surveying, Modeling, and Representation, IGI Global, Hershey. doi:10.4018/978-1-4666-8379-2 Available: http://www.igiglobal.com/book/handbook-research-emerging-digital-tools/123121 [2/29, 2016].

EASTMAN, C., TEICHOLZ, P., SACKS, R. and LISTON, K., 2011. BIM handbook: a guide to building information modeling for owners, managers, designers, engineers and contractors. Second Edition. New Jersey: Wiley.

FAI, S., FILIPPI, M. and PALIAGA, S., 2013. Parametric modeling (BIM) for the documentation of vernacular construction methods: a BIM model for the commissariat building, Ottawa, Canada. ISPRS Annals of the Photogrammetry, Remote Sensing and Spatial Information Sciences, Volume II-5/W1, 2013 XXIV International CIPA Symposium, 2 - 6 September 2013, Strasbourg, France.

FRISHER, B., 2008. The Rome Reborn Project. How Technology is Helping Us to Study History. University of Virginia, OPEd. Available: http://www.romereborn.virginia.edu/rome reborn 2 documents/papers/Frischer OpEd final2.pdf [2/29, 2016].

GARAGNANI, S. and MANFERDINI, A., 2013. Parametric accuracy: Building Information Modeling process applied to the cultural heritage preservation. International Archives of the Photogrammetry, Remote Sensing and Spatial Information Sciences, Volume XL-5/W1, 3D-ARCH 2013 - 3D Virtual Reconstruction and Visualization of Complex Architectures, 25 - 26 February 2013, Trento, Italy.

GIL, A., 2011. Modelos Digitais - Geometria associativa: particularidade da musealização de monumentos em extensão. O Aqueduto das Águas Livres como caso de estudo. Universidade Técnica de Lisboa - Instituto Superior Técnico.

GIL, J., KARIMI, K., PENN, A. and VAROUDIS, T., 2015. The space syntax toolkit: Integrating depthmapX and exploratory spatial analysis workflows in QGIS, 10th International Space Syntax Symposium, London. 
HILLIER, B. and HANSON, J., 1984. The Social Logic of Space, Cambridge University Press, Cambridge.

MÉGRE, R. and SILVA, H., 2014. "Os Conventos na imagem urbana de Lisboa". Monastic architeture and the city, Debates, $n^{\circ} 6$. Coimbra: cescontexto, pp.108-124.

MURPHY, M., MCGOVERNA, E. and PAVIA, S., 2011. Historic Building Information Modeling - adding intelligence to laser and image based surveys. International Archives of the Photogrammetry, Remote Sensing and Spatial Information Sciences, vol.XXXVIII-5/W16, ISPRS Trento 2011 Workshop, 2-4 March, Trento, Italy.

MURTEIRA, H. and RODRIGUES, P., 2014. "Lisbon 31st October 1755: the city imaginary museum". THE CITY AS A VIRTUAL MUSEUM RECONSTRUCTING THE PAST TO LIVE IN THE PRESENT, Lisboa, ISCTE - IUL - Escola de Sociologia e Politicas Publicas.

RUA, H. and GIL, A., 2014. Automation in heritage - Parametric and associative design strategies to model inaccessible monuments: The case-study of eighteenth-century Lisbon Águas Livres Aqueduct. Digital Applications in Archaeology and Cultural Heritage. Available: http://dx.doi.org/10.1016/j.daach.2014.06.002i [2/29, 2016].

SANTAGATI, C., 2005. 3D laser scanner aimed to architectural heritage survey: From the point's cloud to the geometrical genesis determination. International Society Of Photogrammetry And Remote Sensing, Volume XXXVI, Part 5/W17, 3D-ARCH 2005: Virtual Reconstruction and Visualization of Complex Architectures, 22-24 August, 2005, Mestre-Venice, Italy.

SEAV, 2012. Principlies of Seville. Available: http://www.arqueologiavirtual.com/carta/?page id=189 [2/29, 2016].

SEQUEIRA, M., 1939. O Carmo e a Trindade. Lisboa: Câmara Municipal de Lisboa, Volume III.

UNESCO, 2009. The London Charter. For the computer-based visualisation of cultural heritage. Available: http://www.londoncharter.org/ [2/29, 2016]. 